\title{
WEED INFESTATION IN MULBERRY GARDEN
}

\author{
BHALERAO R.S. ${ }^{1}$, HIWARE C.J. ${ }^{2}$ AND AVHAD S.B ${ }^{3}$
}

Keywords: Weeds, mulberry garden.

Aurangabad region has great potential for sericulture; its environment is good for this industry. The availability of irrigation water in the command area of Jayakwadi projects has further brightened the prospects of sericulture in Aurangabad region. In Aurangabad district during the year 2001-2002, there was increasing trend in sericulture industry. Total 90 villages with 277 farmers were carried out sericulture practice in this district with a total of 319 acres of Mulberry plantation. (Hiware et al., 2004).

The studies were carried out at Sericulture Research Unit, Zoology Department, Dr. B. A. M University, Aurangabad (Maharashtra). Aurangabad is situated on $19^{\circ} 52^{\prime}$ North Latitude and $75^{\circ} 18^{\prime}$ East Longitude. The mean annual rainfall is about $750-850 \mathrm{~mm}$. The mean temperature range varies from $15^{\circ} \mathrm{C}$ to $43{ }^{\circ} \mathrm{C}$ (minimum during December and maximum in May). The mean relative humidity ranges from 55\% to $95 \%$ (minimum during summer months and maximum during monsoon months).

There are two kinds of superficial formations, one consisting of upland soil derived from the decomposition of the rocks on the spot, peculiar to the hilly region, sand the other alluvial soil, deposited by water, belonging to the plains and to the hollows in the valleys of rivers. The higher portions of the valleys are likewise shallow and undulating, and much intersected with nallas, Black soils occasionally occur, resting either on calcareous beds or on partially decomposed globular basalt. In the river valleys lower down, a light-brown kankary alluvium is the prevailing soil.

About 15,000 plant species occur in India of which around 160 species are of economic importance. Over 300 wild relatives of crop plants are also reported from Indian sub-continent. Looking into the status of endangered, rare and threatened species particularly with reference to economic plants carry importance. It is obvious that such species should be collected and conserved before they finally disappeared forever. India is recognized as one of the twelve mega-biodiversity centers of the world and covers $11.90 \%$ of the world flora. In India, mulberry is not only cultivated for sericulture but for fruit, timber, fuel, and fodder too (A.Tikader and S.B.Dandin, 2006). Mulberry, a perennial deciduous plant is reported to have originated in China, the primary centre of the plant origin (Vavilov, 1926). Apart from the Indian species, namely $M$ indica, $M$

\footnotetext{
${ }^{1-3}$ Department of Zoology, Dr. Babasaheb Ambedkar Marathwada University Aurangabad-43 I 004.M.S., India, Bangladesh.
} 
alba, $M$ serrata, and $M$ laevigata, which are considered as indigenous. Many mulberry varieties were introduced in India from other countries i.e., $M$. multicaulis, $M$. bombycis, $M$. nigra, M. alba, $M$. rotun-diloba, $M$. cathayana, and M. ttiliaefolia are the prominent ones. Thus the conservation of mulberry genetic resources has become very much essential to meet the desired objectives of longterm management and utilization.

Mulberry, which is mainly used as a lonesome of silkworm feed for silk production has been introduced in different countries of the world. The mulberry spreads from the temperate areas of North West and Central Asia, Europe, and North America through the tropics of Asia, Africa, and Latin America to the Southern Hemisphere (South Africa and South America). Mulberry varieties grow in various environments from sea level to altitudes of $4000 \mathrm{~m}$ and domestication of mulberry must have been started several thousand of years ago for silkworm requirement (FAO, 1990). Mulberry also grows from humid tropics to semi-arid lands like in the near East with $250 \mathrm{~mm}$ of annual rainfall and South West of the USA (Tipton, 1994).

The weeds in mulberry plantation retards growth, leaf yield and make the host susceptible to various diseases. Weeds growing in mulberry fields pose a serious problem for mulberry plantation; reducing the leaf yield significantly (Sikdar et al., 1981; Srinivasan et al., 1987; Shivakumar et al., 1994).The Weed is considered as a plant where it is not desired (Bernchey, 1920; Bailey and Bailey, 1941). So from ecological and sericultural point of view, these plants are to be controlled.

The Weed is considered as a plant where it is not desired and unwanted plants grown in wanted area (Bemchey, 1920; Bailey and Bailey, 1941). The growing of weeds in mulberry garden leads the competition to mulberry plant for uptake of nutrients which causes to reduce the yield and quality of mulberry leaf (Muniyppa et al. (2000); Jaiswal et al. (2006). From the economic point of view, the growing of weeds in mulberry plantation pose a serious problem, which affects to reduce the yield of leaf and automatically which affects on the production of cocoon and silk (Isaiarasu et al., 2005; Setua et al., 2008). So weeding is very essential every year, whereby their effect can be minimized in mulberry garden.

A survey on weed infestation was carried out in mulberry garden in three different seasons, namely rainy, winter, and summer during study period of 20042005 and 2005-2006. Collected weeds were identified and placed under respective families with the help of Flora of Marathwada (V. N. Naik, 1998). The preparation of herbarium as methods for identification of weed specimen were collected from mulberry garden and dry it at normal temperature for two weeks, 
which is wrapped in paper and then stick on herbarium sheet with the help of sticky substances.

Identified weed species in mulberry garden have been presented in Table 1. The occurrence of 58 weeds species belonging to 16 families names belongs: Acanthaceae (1), Amaranthaceae (4), Asteraceae (9), Caesalpinaceae (2), Commelinaceae (3), Convolvulaceae (5), Cyperaceae (1), Euphorbiaceae (4), Fabaceae (10), Lamiaceae (1), Malvaceae (2), Mimosaceae (2), Nyctaginaceae (1), Oxalidaceae (1), Poaceae (11), Tiliaceae (1). The highest numbers of weed species were observed in the family Poaceae, followed by the family Fabaceae and Asteraceae. These three were the dominating families in respect of higher number of occurrence of species in survey area.

Table 1. Weed infestation along with their respective families.

\begin{tabular}{cll}
\hline Sr. No. & \multicolumn{1}{c}{ Name of weeds } & \multicolumn{1}{c}{ Family } \\
\hline 1 & Justicia vahlii Roth. & Acanthaceae \\
2 & Achyranthus aspera L. & Amaranthaceae \\
3 & Alternanthera sessalis L. & Amaranthaceae \\
4 & Amaranthus hybridus L. & Amaranthaceae \\
5 & Amarnathus viridis L. & Amaranthaceae \\
6 & Agerantum conzyoides L. & Asteraceae \\
7 & Bidens biternata (Lour.) Merr. & Asteraceae \\
8 & Cat harm us tinctorius L. & Asteraceae \\
9 & Eclipta alba (L.) Hassk. & Asteraceae \\
10 & Lagascea moilis Cay. & Asteraceae \\
11 & Parthenium hysterophorus L. & Asteraceae \\
12 & Synedralla nudUlora L. & Asteraceae \\
13 & Tridax procumbens L. & Asteraceae \\
14 & Vernonica cinerea (L.) Less. & Asteraceae \\
15 & Cassia obtusifolia L. & Caesalpinaceae \\
16 & CassiatoraL. & Caesalpinaceae \\
17 & Commelia communis L. & Commelinaceae \\
18 & Commelia eracta L. & Commelianceae \\
19 & Commelina bengnalensis JRA. & Commelianceae \\
20 & Convolvulus arvensis L. & Convolvulaceae \\
21 & Ipomoea indica (Berm.) Merr. & Convolvulaceae \\
22 & Ipomoea maxima L & Convolvulaceae \\
23 & Ipomoea postigridis L. & Convolvulaceae \\
\hline & &
\end{tabular}


Table 1. Cont'd.

\begin{tabular}{cll}
\hline Sr. No. & \multicolumn{1}{c}{ Name of weeds } & \multicolumn{1}{c}{ Family } \\
\hline 24 & Ipomoea sinensis (Ders.) Choicy. & Convolvulaceae \\
25 & Cyperus strigosus L. & Cyperaceae \\
26 & Acalypha indica L. & Euphorbiacae \\
27 & Euphorbia hirta L. & Euphorbiacae \\
28 & Euphorbiaprunfolia Jaca. & Euphorbiacae \\
29 & Phyllamthus niruri Auct. & Euphorbiacae \\
30 & Alysicarpus ovalifolius Leonard & Fabaceae \\
31 & Crotalariajuncea L. & Fabaceae \\
32 & Crotairia medicaginea Lamk. & Fabaceae \\
33 & Crotalaria notonhi Wt. and Ar & Fabaceae \\
34 & Goniogyna hirta (Wilid) Au & Fabaceae \\
35 & Indigofera cordifolia Heyne ex Roth. & Fabaceae \\
36 & Indigofera duthiei Drum ex Naik & Fabaceae \\
37 & Indigofera glandulosa Wendi. & Fabaceae \\
38 & Indigofera linfolia L. & Fabaceae \\
39 & Tephrosiapurpurea L. & Fabaceae \\
40 & Lavandula bipinata (L.) 0. Ktze & Lamiaceae \\
41 & Sida acuta Burm. & Malvaceae \\
42 & Sida cordfolia L. & Malvaceae \\
43 & Mimosa pudica L. & Minosaceae \\
44 & Neptunia triguetra (Wilid) Benth. & Minosaceae \\
45 & Boerharia repens L. & Nyctaginaceae \\
46 & Oxalis corniculata L. & Oxalidaceae \\
47 & Brachiaria erucjformis L. & Poaceae \\
48 & Cynodon doctylon L. & Poaceae \\
49 & Dactyloctenium sindicum Boiss. & Poaceae \\
50 & Digitaria stricta Roth. & Poaceae \\
51 & Dimeria connivens L. & Poaceae \\
52 & Eragrostis bjfaria (VahI.) Bot. & Poaceae \\
53 & Eragrostis ciliaris Staff. & Poaceae \\
54 & Eragrostispoacides D. Beaul. & Poaceae \\
55 & Heteropogon contortus (L.) D. beau! & Poaceae \\
56 & Iseilema laxum Hack. & Polanocenchrisjacguenmonti Jaub. \\
58 & Triumfettapentendra A.Rich. & \\
\hline & & Poaceae. \\
\hline
\end{tabular}


Environmental factors have great influence on phenological behaviour. This is described by Leith (1975) as the study of the timing with regard to biotic and abiotic factors and interaction of different phenophases of same or different species. From economic point of view, it is difficult to maintain weed free plantation. So, weeding will be very essential in the month of April, June, and November for survey area.

\section{Acknowledgements}

The authors are thankful to the University authorities and Prof. and Head, Dept. of Zoology, Dr. B.A.M.University, Aurangabad for providing the necessary facilities for carrying out this work.

\section{References}

A.Tikader and S.B. Dandin, 2006: Maintenance and Utilisation of Mulberry (Morus Spp.) Genetic Resources Proceedings of the Reports Presented at the International Jubilee Scientific Conference - "Problems of Maintenance and Utilisation of Mulberry and Silkworm Genetic Resources” p: 3-14.

Bailey and Bailey, E. Z. 1941. Hortaus the Second. Macmillan, New York, pp. 778.

Brenchley, W. E., 1920. Weeds of Farm-land, Longmans, Green, London.

FAO, 1990. Sericulture Training Manual. FAO Agricultural Services Bulletin, 80, Rome, pp. 117.

Hiware, C. J., D. A. Hake and N.B. Bawage. 2004. Status of sericulture industry in Aurangabad district, Maharashtra state, India. Natl. J. life Sciences 1(2): 471-472.

Isaiarasu, L. and R. Ganesan. 2005. Weed flora in a mulberry garden near Sivakasi, Tamil Nadu. Bionotes 7(2): 64-65.

Jaiswal, K., R. Goel, R. Kumar and S. K. Gangwar. 2006. Effect of different soil mulches on mulberry leaf yield and leaf moisture content. In: Abstr. of NatI. Semi. on Soil Health and Water Management for Sustainable Sericulture, Regional Sericultura! Research Station, Kodathi, Bangalore, India, 27-28 Sep., 2006, pp. 30.

Leith, H., 1975. Productivity of major Vegetative Units of World. Ibud, pp. 203-216.

Muniyappa, T. V. and H. R. Shivakumar. 2000. Crop weed competition in mulberry. In: Proceedings of the National Seminar on Tropical Sericulture, 1999, Department of Sericulture, University of Agricultural Sciences, GKVK, Bangalore, India, 28- 30 December 1999, 1: 76-78,

Naik, V. N., 1998. Flora of Marathwada, Vol. I and Vol. II, Amrut Publication, Aurangabad, Maharashtra, India.

Setua, G. C., M. Setua, A. K. Dutta and B. Saratchandra. 2008. Botanical weed management in irrigated mulberry: A new approach. Indian Silk 46(11): 15-17.

Shivakumar, H. R., N. C. Prthibha and T.V. Muniyappa. 1994. Effect of chemical weed control on nutrient uptake by common mulberry (Morus australis) and associated weeds. Indian J. Agron. 39(2): 277-281. 
Sikadar, A. K., S. Krishnaswami and A. Bharathi. 1981. Effects of weed competition on growth and leaf-yield of mulberry. Indian J. Seri. 20(1): 7-10.

Srinivasan, E. B., M. R. Subbaswamy, A. K. Sikdar, A. Bharathi and M. S. Jolly. 1987. Effects of weed density value of mulberry (Morus indica L.). Indian J. Seri. 26(2): 72-75.

Tipton, J. 1994. Relative drought resistance among selected South Western landscape plants. Journal of Arboriculture 20(3): 151 - 155.

Vavilov, N. I. 1926. Studies on the origin of the cultivated plants. Trudy Byuro Prikl. Bot. 16: $139-248$. 